\title{
Future proofing the principle of no significant harm
}

\author{
Joyeeta Gupta ${ }^{1}$. Susanne Schmeier ${ }^{2}$
}

Accepted: 16 October 2020 / Published online: 2 November 2020

(c) The Author(s) 2020

\begin{abstract}
The principle of 'no significant harm' as a way of addressing transboundary environmental challenges is both inadequately researched and inadequately implemented in many parts of the world. This paper addresses the questions: What is the nature of transboundary harm in the Anthropocene? Is the principle of no significant harm able to address current and preempt future transboundary harm in the field of water and environmental law? This special issue has focused on this principle in the arena of water law. This article integrates the findings in the context of a broader understanding of global harm in the Anthropocene. We draw 4 conclusions. First, conceptually harm is moving beyond direct inter-state harm between neighbouring countries to a multi-directional, multi-actor/multi-level harm, which is increasingly creeping and cumulative, with growing spatial and temporal characteristics. It thus requires moving beyond quibbling over what is 'significant' harm to recognize the climate emergency, the sixth biodiversity extinction, the huge damage to water systems and to realize that the threshold of ecosystem and human tolerance of damage are reducing rapidly. Second, however, the no-harm principle tends to be better developed in qualifying sovereignty in relation to transboundary harm on rivers than in the broader environmental and development arena as demonstrated by agenda 2030 which reverts to full permanent sovereignty. Third, legal scholarship, however, does provide a wide range of instruments for addressing harm before it occurs, after it has happened, and considering the differentiated economic capacity of the actors. Finally, the larger problem is that it is not individual projects or programmes that cause problems as much as national prioritization of economic growth which has led to externalizing the environment. The no-harm principle will be ineffective if it cannot be used to question the content of 'growth'-led policies. There is need to future proof the no-harm principle.
\end{abstract}

Keywords No-harm $\cdot$ No significant harm $\cdot$ Sovereignty $\cdot$ Responsibility $\cdot$ Equity $\cdot$ Water law $\cdot$ Environmental law $\cdot$ Sustainable development goals

\section{Abbreviations \\ BAT Best available technology}

Joyeeta Gupta

j.gupta@uva.nl

1 Governance and Inclusive Development, Amsterdam Institute for Social Science Research, University of Amsterdam, IHE-Delft Institute for Water Education, Delft, Netherlands

2 IHE-Delft Institute for Water Education, Delft, Netherlands 


$\begin{array}{ll}\text { BATNEEC } & \text { Best Available Technology Not Entailing Excessive Costs } \\ \text { ICJ } & \text { International Court of Justice } \\ \text { ILC } & \text { International Law Commission } \\ \text { NCP } & \text { Nature's contributions to humans } \\ \text { PCA } & \text { Permanent Court of Arbitration } \\ \text { SDG } & \text { Sustainable development goals } \\ \text { SI } & \text { Special issue } \\ \text { UNGA } & \text { United Nations General Assembly }\end{array}$

\section{Introduction}

If the principle of not causing significant harm (or simply the 'no-harm' principle) to others in international law had been effective in preventing significant harm, much of the huge accumulated damage that human activities have caused to the environment and each other would not have occurred. The United Nations Environment Programme's 2019 Global Environment Outlook-6: healthy planet, healthy people (Ekins et al. 2019) records the huge human damage caused to the atmosphere, water, land, biodiversity, and oceans in the Anthropocene and concludes that the existing governance system is scarcely able to address the damage to the environment and hence damage to human well-being and health. This shows that international law addressing significant harm caused to other states and natural ecosystems is developing very incrementally, while the harm caused is growing exponentially.

There is extensive research on the no significant harm principle in the field of international water law (Dellapenna/Gupta 2008; Salman 2010; Brooks 2015). This special issue reviews this knowledge in terms of the principles of international water law (McIntyre; Tanzi, this SI) and their application to specific sectors or challenges (e.g. Tignino \& Bréthaut; Rieu-Clarke; Speijkers; Schmeier this SI) or specific regions (Zinganshina \& Janusz-Pawletta, this SI). Their key findings are presented in the editorial. Some scholars also focus on the legal implications of new forms of water resources development such as cloud seeding or rainwater harvesting (Simms 2010; Larson 2016) and cyberspace (Buchan 2016). However, there is little research on conceptualizing the potential and the limits of the no significant harm principle to ensure that it successfully anticipates, reduces, or mitigates harm. Legal scholars are generally monodisciplinary, highly specialized and focus on what is happening as opposed to what needs to happen to address future problems. This leads to a relatively narrow focus on past challenges and how states have dealt with them, as opposed to imagining what the future of transboundary challenges is likely to be and to promote developments that might pre-empt such significant harm (Gupta and Ceylan 2020). This paper aims to address this gap and asks: What is the nature of transboundary harm in the Anthropocene and is the principle of no significant harm able to address current and pre-empt future transboundary harm in the field of water and environmental law? This paper combines 3 approaches: it synthesises the insights from the papers in this SI, reviews the broader literature on the no significant harm principle and related principles, and explores the emerging and changing landscape of harm and its implications for the principle of no significant harm in the future. This is a large field, and so we only present an overview of the themes.

This paper explores the changing landscape of transboundary harm (see 2) and the state of current water and environmental law to implement the no significant harm principle (see 
3) before proposing a framework for elaborating on the no significant harm principle (see

4) and then drawing conclusions on how to address harm in the future (see 5).

\section{The changing landscape of transboundary harm: conceptualizing harm}

In the field of transboundary water resources (rivers, lakes, and aquifers), harm can occur when one state increases its demand for, and/or pollutes, water to meet its agricultural, industrial, and household needs but in doing so affects another state. With limited resources relative to growing demand and in the context of globalization, population growth, and urbanisation, the pressure to ensure food security, (bio-)energy, and pursue economic growth has increased pressure on resources and ecosystems beyond sustainable levels. This can cause substantial harm to neighbouring states. This also implies that as societies develop, the concept of harm becomes much more complex.

We identify seven dimensions of harm: first, harm is not unidirectional but bi- and multidirectional. While some argue that the no significant harm principle is favoured by downstream states to protect themselves against potentially damaging upstream developments, harm can also be caused by downstream states to upstream states (Salman 2010). Reduced water flows and water pollution affect downstream countries, while the reduced ability of fish to swim upstream or foregone navigation potentials affects upstream countries. Moreover, existing uses in downstream states can affect the ability of upstream states to develop their water resources. Recent disagreements around upstream dam developments affecting existing downstream uses, e.g. on the Nile, the Helmand, or the Mekong rivers illustrate this. This multi-directional nature of harm is so far insufficiently reflected in the no significant harm principle and its implementation.

Second, there is increasing complexity in the source and impact of harm. While the no significant harm principle builds on harm caused by (the activities in) one state to another state, the sources and victims of harm-and their inter-relationships-are more complex. Harm may not be simply transboundary harm between neighbouring states as unitary entities, but a complex reflection of multi-level harm that occurs at all levels simultaneously, involving multi-level accountability of multiple actors in both states. This was demonstrated when the Kosi river barrage collapsed in 2008 in Nepal with huge damage to communities in both Nepal and India; the actors involved not only local neighbours across the borders, but also regional and national governments of both countries (Shrestha et al. 2010). Harm may also be caused by the joint activities of riparian countries. The agreement between the USA and Mexico on the Colorado, for instance, included provisions for joint actions to mitigate harm that was caused jointly (Bussey 2018). Moreover, harm can arise not only from an illegal or prohibited activity, but often also from a legal development activity and thus an activity that is encouraged through policy and is seen as legal and legitimate and essential for national development. In other words, harm to other states may have to be balanced against harm to one's own people caused by foregone development. The harm is either caused to local people or to neighbouring countries and by increasing population pressure and socioeconomic development needs. This leads to dilemma's and governments may try to gain legitimacy by pushing decisions in favour of one direction. For example, water shortage may lead one country to build storage dams reducing flows downstream as between India and Pakistan through the Kishenganga dam (Qureshi 2017). Furthermore, states also have responsibility towards people who live beyond the 
river basin-which has led, inter alia, to inter-basin transfer schemes that might cause harm within a basin but benefit populations outside the basin. And finally, harm may be caused overwhelmingly by the rich but may have differentiated impacts on the rich and poor, the urban and the rural, reproducing existing inequalities (Gupta et al. 2020). International water and environmental law so far does not sufficiently incorporate the complexity of harm described above.

Third, harm can be more or less direct and immediate: if harm relates to alterations to the quality, quantity, and flow of water, this can occur directly and indirectly. Direct harm may be caused by building a storage dam that affects water flows (Qureshi 2018). The harm can be indirect-where it affects groundwater or causes land subsidence and such harm has generally not been included in transboundary agreements such as the one between the USA and Mexico on the Colorado (Bussey 2018). The harm can be very indirect where it affects water flows through climate change (Qureshi 2018), geoengineering, deforestation, the use of modern technologies, and other such activities. Harm can be immediate as in an accident (e.g. the Kosi barrage break) or lead to creeping and cumulative harm (as with drought and sea-level rise) over time. The principle of no significant harm and its implementation in various basins does not yet sufficiently account for such indirect or non-immediate effects (as available instruments to address harm, in the form of international basin treaties and specific mechanisms such as prior notification and consultation typically rely on relatively narrow assessments of the impacts of a planned measure on the watercourse and hardly ever take into account indirect effects such as the future impacts of climate change or developments beyond the individual project)—but will need to do so in the future.

Fourth, harm has spatial and temporal dimensions: on the spatial dimension, it can occur to neighbouring riparian countries but also to countries far away. The harm can even result from progressive and entirely unintended measures: e.g. if India uses drip irrigation because of water shortage, this can increase evaporation and affect rainfall in Sub-Saharan Africa (de Vrese et al. 2016); if a great green wall is built in China and Sub-Saharan Africa - this can affect the hydrological cycle (Filoso et al. 2017). On the temporal dimension, harm is linked to both the past and the future. Existing water uses affect the water plans of late comer's to development. While the Watercourses Convention (UNGA 1997) tried to address the challenges of late comers by making provision for future uses, it has not been ratified by many countries. Moreover, harm can also occur in the future, affecting future generations - we know that the accumulated disposal of antibiotics in water streams can seriously affect health care in the future (Ekins et al. 2019).

Fifth, all activities have an impact and the question is what is 'substantial' or 'significant' harm. Is the problem of climate change, increasingly referred to as a climate emergency very close to causing irreversible and also 'significant harm'? Is the loss of biodiversity equivalent to a sixth extinction event long past the qualification of 'significant harm'? Different actors and states will often have a different understanding of what makes the harmful effects of a project significant or substantial, and in many arenas, this debate is being avoided.

Sixth, the understanding of significant harm will change over time. The tolerance for harm may be lower in 2030 as opposed to the past and even lower in 2050. This will be not only because of the cumulative damage already done to local to global ecosystems, but also because new knowledge may expose the greater risks of such harm. One dam may not be a challenge, but 40000 dams add up cumulatively to significant harm at the global level. In the future, the threshold level will keep going down as global/ local tipping points and planetary boundaries are approached. Given the uncertainty of 
cause-impact relationships, proof of harm becomes even more complicated, and especially proof of harm to future generations (see Fig. 1).

And finally, the concept of state responsibility might not hold perfectly for the new types and dimensions of harms addressed above: states can arguably not be regarded as unitary actors anymore and responsibility can be collective and individual, with specific actors causing specific problems. While research is increasingly exploring challenges relating to state responsibility in the context of harm (Kyllönen 2018; Takano 2018), this remains insufficiently developed to deal with future challenges. Moreover, the practical implementation of the no significant harm principle continues to rely on state-centred mechanisms (international basin treaties, notification and consultation mechanisms, river basin organizations, etc.).

The above 7 characteristics of the changing landscape of harm (see Fig. 1) are necessary to understand in order to prevent significant harm and/or address it once it occurs. To simply address state-to-state harm of a direct causal activity (from an act prohibited by international law) is a tiny part of the story of harm in the Anthropocene which is characterized by massive withdrawals of resources, massive changes to land and waterscapes and massive pollution of global ecosystems, including through causing climate change. Harm to people and nature may require us to rethink our development paradigm, and the current discussions on the no significant harm principle are insufficient to do so as the following section shows.

State/collective responsibility Individual actor responsibility

Changing threshold level of substantial harm and to whom

Reduced tolerance for harm over time Uncertainty, causality, burden of proof, proof Direct, two-directional, multi-level, multi-actor immediate

A
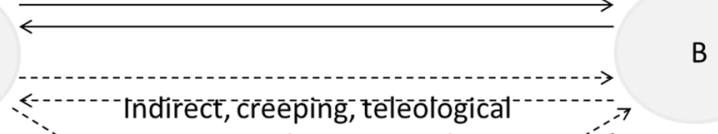

Approaching regional tipping points/ planetary boundaries

Harm caused by:

- Legal/desirable/hazardous activities

- Rich/poor countries/people

- Past/present/future generations
Harm caused to:

- People/industry/ecosystems/pro-

C tected sites

- Rich/poor countries/peoples

- Current/future generations

Fig. 1 Conceptualizing harm 


\section{The principle of no significant harm}

\subsection{Introduction}

The principle of not causing (significant) harm to others has a long pedigree in domestic and international law. Within international law, the no-harm principle was developed in the context of activities undertaken by one state that affected another state. Air pollution was an early issue area to give rise to claims to stop harm (Trail smelter case 1938 and 1941). Other concerns followed suit, including in relation to plant protection and animal conservation, nuclear tests, and the protection of cultural and natural heritage and/or (marine) ecosystems. The principle has, accordingly, been reflected in environmental declarations, water treaties, and some case law, but was omitted in some global environmental treaties (see 3). Ironically, it was also not included in Agenda 2030 (UNGA 2015) which specifies the common 17 environmental and socio-economic goals of global society which aim in essence to reduce harm. There is also much debate on how central it has been in the discussions on state responsibility within the International Law Commission.

\subsection{The principle of no significant harm in international water law}

This section reviews the current state of the no significant harm principle within water law including and going beyond this SI. This SI reveals 5 trends in water law. First, the dominant principle of absolute territorial sovereignty was gradually replaced by limited territorial sovereignty-i.e. that states cannot allow activities within their jurisdiction to cause harm to others. This limited sovereignty is seen as a customary rule of international law (Beyerlin and Marauhn 2011: 44) and an accepted obligation of all states (Sands and Peel 2012: 195). The specific notion of not causing significant harm to others is explicitly included in the 1997 UN Watercourses Convention (UNGA 1997), the 1992 Helsinki Convention (Water Convention 1992), the Ganges Water Treaty (1996; although it does not provide for dispute resolution (Pratap 2018)) and the Mahakali Treaty (1996). Court cases have also referred to this principle. For instance, in the 1997 Gabĉikovo-Nagymaros case (ICJ 1997) and the 2010 Pulp Mills case, the International Court of Justice (ICJ) reconfirmed the importance of environmental protection in a transboundary setting (ICJ 2010). In the 2013 Kishenganga case, the permanent court of arbitration referred to the Trail Smelter arbitration and pointed out that 'there is no doubt that states are required under contemporary customary international law to take environmental protection into consideration when planning and developing projects that may cause injury to a bordering state' (PCA 2013, 169, paragraph 449) and that, accordingly, states have 'a duty to prevent, or at least mitigate significant harm to the environment when pursuing large-scale construction activities' (PCA 2013, 112, paragraph 449; Kuokkannen 2002). The principle of no harm is a compromise between the principles of absolute territorial sovereignty and absolute territorial integrity.

Second, the no-harm principle is not an absolute principle forbidding any harm, but aims at addressing substantive harm and is a due diligence obligation (McIntyre 2017: 241). In this context, due diligence implies that the harm must have been foreseeable for the state of origin on the basis of current knowledge. Foreseeability depends on the availability of data, information and knowledge about the river, its flow regime and its ecosystem in a specific context. 
Third, water law scholars debate on whether the principle of no-harm stands equal to the principle of equitable and reasonable utilization and needs to be interpreted in an integrated manner (Tanzi, this SI), or whether the principle of equitable and reasonable utilization provides the cardinal, overarching rule, with the no-harm principle as a subordinate obligation (McIntyre 2017: 240; this SI) or whether, in light of increasing challenges, no harm should actually prevail over reasonable and equitable utilization. The link between equity and no harm could provide a win-win framework in law (Tanzi, this SI) strengthened potentially through a link to human rights law (Spijkers, this SI). There is increasing recognition that the harm must be dealt with equitably. In the Mahakali river, the parties have agreed not to use, obstruct, or divert water and this could lead to maximizing net benefits (Salman and Uprety 1999). The need for harm to be shared equitably between states has been established in Minute 323 on the Colorado river between the USA and Mexico (Bussey, 2018).

Fourth, the no-harm principle entails prohibitive and preventive elements as well as remedies. It forbids states to cause significant harm; it obliges states to take adequate measures to control or regulate sources of potential harm in advance; and it calls for reparation of harm done. The preventive dimension of no-harm is crucial as it regulates states' behaviour before harm is caused and helps prevent disputes. It implies procedural duties including the exchange of information on projects in a timely manner and the principle of prior notification and consultation (Schmeier, this SI), notifications in the case of environmental emergencies, the principle of transboundary environmental impact assessment, and the provision of environmental information and access to justice also for non-residents of the project planning state (Beyerlin and Marauhn 2011: 44). The legal status, development, and implementation of these principles vary considerably. Most legal scholars acknowledge the customary law status of the duty to exchange information, the principle of prior consultation, and the duty of early warning in the case of emergencies, but not of access to information and access to justice (Beyerlin and Marauhn 2011: 45). The principles of prior information sharing and transboundary environmental impact assessments reaffirmed by the ICJ in the 2010 Pulp Mills case (ICJ 2010).

Fifth, in an increasingly complex world where state and business actors are trying to address a variety of development, water, and energy goals, large infrastructural projects are being initiated without clear understanding of the harm that these can cause directly or indirectly to others and how responsible states and private actors are (Rieu-Clarke, this SI).

In summary, while a normative framework on what is significant harm is emerging, this framework is conservative and incremental and faces elaboration (e.g. Ziganshina and Janusz-Pawletta when discussing Central Asia, this SI) and compliance challenges (Barrett 2003: 122). Interpreting the direction, source, causality, nature, impact, and size of harm is challenging. Scholars are optimistic that many of these principles have become part of customary law, but state reluctance to ratify the global water conventions and to address these issues may question this underlying optimism.

\subsection{The principle of no harm in broader environmental law}

The pessimism regarding the progress of the no harm principle is also evident in more general international environmental law, namely by its absence in recent international environmental treaties. We identify 6 trends here: first, international environmental law recognizes the no-harm principle and has used this to curtail state sovereignty in the Trail Smelter case and the Stockholm (UNGA 1972) and Rio Declarations (UNGA 1992). The 
principle was discussed in the 1996 ICJ advisory opinion on the legality of the threat or use of nuclear weapons. Harm has to reach a certain level of significance or seriousness, but what that level is remains challenging. The de minimus rule states that 'there must be a real impairment of use, i.e. a detrimental impact of some consequence upon, for example, public health, industry, property, agriculture or the environment in the affected state' (ILC 1990: 36).

Second, however, major international environmental treaties do not include the no-harm principle in the operational part of the text. This list includes the United Nations Framework Convention on Climate Change (UNFCCC 1992) and the biodiversity convention (CBD 1992). Since initially it was primarily the rich countries that were responsible for greenhouse gas emissions - they were opposed to any recognition of the no-harm principle and concomitant recognition of liability and compensation (Gupta 1997) and a footnote was added to the titles of articles in the convention to undermine the value of the principles in the climate change convention (Bodansky 1993).

Third, unlike in the water regime where no-harm competes with or complements the principle of equitable and reasonable utilization, in the global environmental regimes the no-harm principle has increasingly morphed into a diffuse 'common but differentiated responsibilities and respective capabilities' principle. It is also complemented by the 'precautionary approach' which is qualified by cost-effectiveness. This indicates an even weaker position of the principle in international environmental law more generally.

Fourth, the International Law Commission prepared draft articles on responsibility of states for Internationally Wrongful Acts, 2001 and draft articles on the prevention of transboundary harm from hazardous activities, but further development of the no-harm principle in relation to activities not forbidden by international law appears to have stalled. The lack of the no-harm principle is especially problematic for the small island states such as Palau who have been wanting to use the general assembly to request a legal advisory opinion from the International Court of Justice; they were apparently dissuaded by richer countries from doing so (Beck and Burleson 2014). Similar tactics may have been used to pre-empt the International Law Commission from working on this issue (Mayer 2014). For example, the scope of the work of the ILC on this topic was reduced (UNGA 2014: A/68/10, para. 168):

(a)Work on this topic will proceed in a manner so as not to interfere with relevant political negotiations, including those on climate change, ozone depletion, and longrange transboundary air pollution. The topic will not deal with, but is also without prejudice to, questions such as the liability of States and their nationals, the polluterpays-principle, the precautionary principle, common but differentiated responsibilities, and the transfer of funds and technology to developing countries, including intellectual property rights.

Fifth, while Agenda 2030 (UNGA 2015) attempted to bring key global goals together to protect the environment and minimize harm by adopting 17 Goals, it reverts back to promoting full permanent sovereignty over natural resources and does not mention the "no significant harm' principle at all (mentioning harm only in relation to alcohol and gender, mentioning responsibility_in terms of 'shared responsibility' (\#36)), that 'each country has primary responsibility for its own economic and social development' (\#41) and stating: 'we reaffirm that every State has, and shall freely exercise, full permanent sovereignty over all its wealth, natural resources and economic activity' (\# 18). By focusing on shared responsibility and full permanent sovereignty and by not referring to the "no significant harm' principle, this document accepts that there will be harm, even substantial harm, but 
that much of this harm emerges from legitimate economic activity and the only way forward is to accept shared responsibility and collaborating with each other. No guidance is, however, provided on how to do so.

Sixth, there was an attempt to bring back the no significant harm principle within the global pact for the environment. Following an UNGA resolution (UNGA 2018) a draft Global Pact which elaborated, inter alia, on the no significant harm principle was available and an open-ended working group began its work. It however recommended that there should be no negotiations on the subject. Some argue that some states opposed such a Pact and that such a Pact could be worse for the environment. In our view this demonstrates the political challenges and unwillingness to come to grips with a challenging global problem and the need to further elaborate on the no harm principle.

\subsection{Inferences}

While scholars and agreements in the area of transboundary water law are seeing positive developments with respect to the no-harm principle, in the wider environmental arena the no-significant harm principle seems to be subject of debate-some want to see it develop, while others oppose further developments. While the SDGs and the attempt to negotiate the Global Pact demonstrate some degree of multilateral law development, as far back as in 2006, there were increasing trends that multilateralism in a wide range of fields was under threat (Newman et al. 2006) and these trends have only sharpened over the years (Maull, 2018). This might ultimately also impact advances in international water law that is increasingly interrelated with other fields of international (environmental) law.

\section{Towards a broader framework of the no significant harm principle}

\subsection{A broader framework}

Even though there are political hurdles to elaborating the no-harm principle, we elaborate further on the no significant harm principle. We argue that a broader equity framework can look at responsibility for harm and the ability to pay (Dellink et al. 2009). Both would have links to equity (see Fig. 2).

In terms of the no harm principle, the emphasis must be on preventing harm especially as harm is becoming increasingly irreversible. We cluster these into 4 categories: first, where there is certainty of causality, foreseeability, and the likelihood of significant harm (ILC 2001), the prevention principle kicks in. This has been used in the pulp mills (ICJ 2010), Gabĉikovo-Nagymaros (ICJ 1997), and the nuclear weapons advisory opinion (ICJ 1996) cases. Where there is a strong likelihood of irreversible impacts but the causality is uncertain, the precautionary principle (included in the Rio Declaration, the Climate Convention 1992, the UNECE Water Convention, Treaty Establishing the European Community) is applicable (Harremoës et al. 2001; Trouwborst 2007), although its status as a customary law principle remains contested (Birnie et al. 2002; Gaskell et al. 1999). Since uncertainty can range from $0-100 \%$, the legal action for different levels of uncertainties can range from 'stop and frisk' to 'criminal conviction' (Weiss 2006). If harm has not been caused, proving potential harm is challenging; this may require lowering the standard of proof or shifting the burden of proof to the project proposing state, especially in cases of hazardous activities with potential catastrophic consequences (Beyerlin and Marauhn 


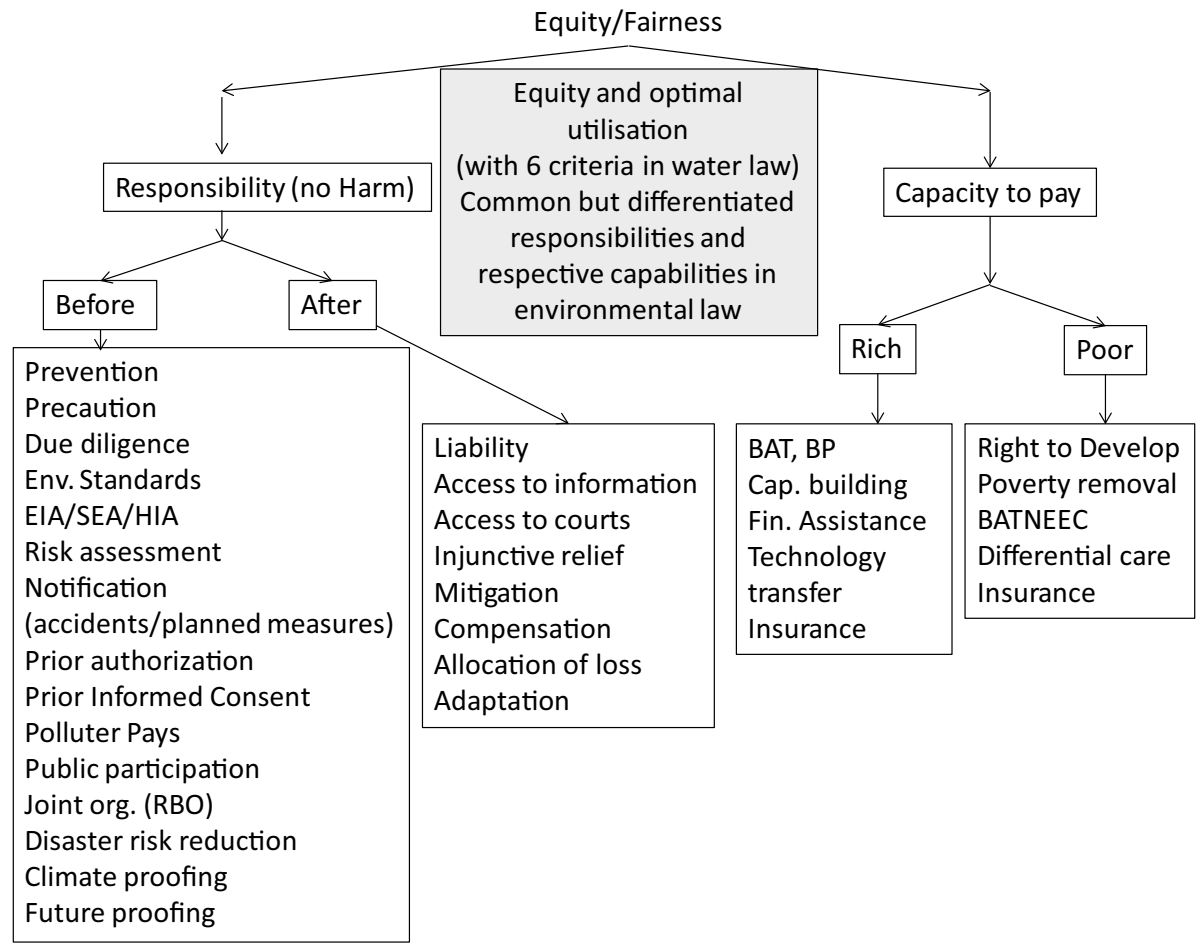

Fig. 2 Different aspects of the no significant harm principle and its relationship with fairness. Source: Building further on Gupta and Sanchez (2013)

2011: 43). State must show 'due diligence' in acting proportional to the risk (Rao 2002; ITLOS Advisory Opinion), especially when the harm is predictable (McIntyre 2017: 241) and the state is capable of acting (Voigt 2008) which links up to the principle of capability (Birnie et al. 2002). Due diligence requires that a state complies with certain obligations (ILA 2014), but these obligations are often not defined, do not have 'unified content' or are too flexible and context related (ILA 2014; Kulesza 2016; Buchan 2016). Due diligence can imply adopting regulatory standards such as best available technologies (BAT) and best available technologies not entailing excessive costs (BATNEEC). Such standards can also be voluntarily used by companies/cities encouraged through the adoption of the polluter pays principle (UNGA 1992, Single European Act (1986)) which requires industry to internalize the cost of pollution or through other market instruments such as tradeable rights.

Second, the no significant harm principle and due diligence requirement could require undertaking strategic environmental assessments, environmental impact assessments, health impact assessments, and broader risk assessments (UNGA 1992; Beyerlin \& Marauhn 2011; ICJ 2010; Craik 2008). However, applying these remains challenging (Knox 2002) and de facto very few basin-specific instruments include these.

Third, due diligence can be shown through notification of (planned) activities and accidents (after harm) to other parties, consulting, and where possible seeking prior informed consent (free prior informed consent if it concerns the lands of indigenous 
communities) as well as taking into consideration informed states' concerns and adapting a planned measure accordingly (e.g. through effective mitigation measures for potential harm).

Fourth, public participation in decision-making may be critical for reducing harm and especially in the context of joint bodies set up by the countries involved to solve possible harm before it occurs. In transboundary waters-such joint bodies exist in many regions of the world, and the conference of the parties to different treaties addresses transboundary harm in global issues. Finally, the threat of crossing planetary boundaries and tipping points calls for disaster mainstreaming advocated for in disaster-related agreements at global level and for climate proofing development programmes.

After harm has occurred, 4 issues arise-access, causality, relief, and adaptation. First, do those (potentially) affected have access to the necessary information through e.g. the freedom of information act? Do they have access to the appropriate courts and standing there? Where future generations can be represented by children, there is a clear actor. When the future generation is yet to be born, the non-identity problem argues that we cannot know what the harm will be because an alternative choice made today might even imply that the same future people may not exist (Attfield 2012); however, the harm may still be caused.

Second, causality is challenging. Causality from blatantly wrongful acts is discussed in the ILC's draft articles on the prevention of transboundary harm from hazardous activities (ILC 2001a) and in the responsibility of states for Internationally Wrongful Acts (ILA 2001b). Proving causality especially in relation to indirect, teleological, creeping harm is difficult. 'Indirect and uncertain' harm was excluded when considering the duty to repair in the Trail Smelter case (Drumbl 2003), and there have been questions regarding the fact that if operators and consumers cause the harm, should the state be responsible (Faure and Nollkaemper 2007; Cullet 2007)? The complexity of modern life and modern harm requires new understandings of causality and liability. The Rio Declaration on Environment and Development (UNGA 1992) states that: 'States shall develop national law regarding liability and compensation for the victims of pollution and other environmental damage. States shall also cooperate in an expeditious and more determined manner to develop further international law regarding liability and compensation for adverse effects of environmental damage caused by activities within their jurisdiction or control to areas beyond their jurisdiction.' Liability can be assumed when reasonable measures were not taken (liability ex delicto); when there is liability under all circumstances (liability sine delicto stricto sensu); and when harm is allowed if equitable and reasonable (liability sine delicto lato sensu). But what is reasonable harm? Harm caused by hazardous and wrongful acts is easier to address-but when are states liable for the normal activities of developing agriculture or energy which causes cumulative damage? There is growing literature (e.g. Faure and Peeters 2011) and litigation (e.g. Peel and Osofsky 2015), but the issue is far from settled.

Relief for the harm caused includes injunctive relief (to stop activities until there is clarity), mitigation (to reduce the harm), compensation (to pay for damages caused), and the allocation of loss (addressing harm caused by activities which are not forbidden by law). The latter is addressed by the 2006 draft principles on the allocation of loss in the case of transboundary harm arising out of hazardous activities (ILC 2006). This document focuses less on state responsibility for the losses caused, but requires states to ensure that private operators within their jurisdiction have insurance or bonds to be able to pay compensation leading to a 'privatized approach to risk' (Foster 2005). The question is whether these draft principles provide adequate guidance and whether this shifts responsibility to individual 
private operators-who cannot know the cumulative effect of all actors for the damage caused to others and who courts may find difficult to hold liable.

The last option is adaptation to harm, and here the questions are-is adaptation still possible where damage is irreversible and who pays? In the climate change regime, adaptation is primarily a national and local responsibility, even though there is some financial assistance from rich countries. And this brings us to the issue of whether there should be differentiation of responsibility based on who can pay.

Differentiating responsibilities is based on the principle of liability (who causes harm should pay) and solidarity (who has the ability), the duty to cooperate under international law, and exceptions - as some of the pollution may be 'survival' pollution (Agarwal and Narain 1990). The problem of harm has to be placed against the context of different speeds of development. Development itself, while striving for better lives for many, can also be a major cause of harm which requires fast-developing countries to compensate least developed countries for the harm caused to them and for the latter's reduced ability to develop in the same manner (e.g. use cheap fossil fuels to enable development). The right to development (UNGA 1986) was meant to enable developing countries and their people to develop, but if development as currently defined itself is problematic, then there is clearly a problem. This was being redesigned as the right to sustainable development. In the climate change convention a strategic shift in a comma turned the right to sustainable development into a right to promote sustainable development and discussions on this latter right have stalled (Gupta and Arts 2018). The point we are trying to make here is that if development activities by virtue of their cumulative use of resources and expulsion of wastes are causing harm, the no-harm principle has to be used to redefine what is development itself and has to question the very content of 'growth' as increases in gross domestic product.

\section{Challenges and the way ahead}

Humans are causing cumulative harm, potentially crossing planetary boundaries (Rockström et al. 2009; Steffen et al. 2015). If such harm is to be contained, the law on not causing significant harm has to make a quantum leap forward. We draw 4 conclusions.

First, conceptually harm is moving beyond direct inter-state harm between neighbouring countries to a multi-directional, multi-actor, and multi-level harm, which is increasingly creeping and cumulative, with growing spatial and temporal characteristics, and requires moving beyond quibbling over what is 'significant' harm to recognize the climate emergency, the sixth biodiversity extinction, and the huge damage to water systems and to realize that the threshold of ecosystem and human tolerance of damage are reducing rapidly.

Second, in the legal arena, there is incoherence in the treatment of: sovereignty subject to the no significant harm principle as in the water law arena, and the shift to full permanent sovereignty as in agenda 2030; the no-harm principle in relation to equitable and optimal utilization as in the water law arena, and its replacement by the common but differentiated responsibility and precautionary principle approach as in other environmental treaties (e.g. The Climate Convention 1992); harm caused by wrongful acts and harm caused by acts that are in themselves not wrongful, even though due diligence applies to state activities generally.

Third, legal scholarship, however, does provide a wide range of instruments for addressing harm before it occurs and after it has happened. It also considers the differentiated 
economic capacity of the actors. The ingredients for a framework for developing the no harm principle thus exist.

Fourth, harm is intricately linked to the way development is defined and current principles, policies, and practices are falling far behind the exponential growth of cumulative transboundary harm increasingly characterized by nonlinearities, uncertainties, and tipping points. Harm has to be linked to the notion of development itself, and strategic environmental assessments may be one way forward. Allocation of loss and the privatized approach to risk may not address the problem.

However, questioning 'growth' is problematic for both rich and poor countries. Nevertheless, if international law is to play a relevant role in creating the boundary conditions for societies, it will have to rapidly develop ideas on how the no-harm principle should be elaborated and use all means possible to promote the progressive development of international law and to pre-empt the potentially negative impacts of the linear growth-oriented resource and waste-intensive global society.

Acknowledgements This paper acknowledges the support of Water Diplomacy project of the IHE Delft Institute for Water Education, the Leaving Fossil Fuels Underground project sponsored by the Netherlands Organisation for Scientific Research (NWO) under Grant Number W 07.303.104, the Earth Commission Project sponsored by the Global Challenges Foundation, and the research time provided by the Amsterdam Institute for Social Science Research of the University of Amsterdam.

Open Access This article is licensed under a Creative Commons Attribution 4.0 International License, which permits use, sharing, adaptation, distribution and reproduction in any medium or format, as long as you give appropriate credit to the original author(s) and the source, provide a link to the Creative Commons licence, and indicate if changes were made. The images or other third party material in this article are included in the article's Creative Commons licence, unless indicated otherwise in a credit line to the material. If material is not included in the article's Creative Commons licence and your intended use is not permitted by statutory regulation or exceeds the permitted use, you will need to obtain permission directly from the copyright holder. To view a copy of this licence, visit http://creativecommons.org/licenses/by/4.0/.

\section{References}

Agarwal, A., \& Narain, S. (1990). Global warming in an unequal world: A case for environmental colonialism. New Delhi: Mimeo, Centre for Science and Environment.

Attfield. (2012). Nolt future harm and future quality of life. Ethics, Policy and Environment 14(1): 11-13.

Barret, S., \& Stavins, R. (2003). Increasing participation and compliance in international climate change agreements. International Environmental Agreements, 3, 349-376.

Beck, S., \& Burleson, E. (2014). Inside the system, outside the box: Palau's pursuit of climate justice and security at the United Nations. Transnational Environmental Law, 3(1), 17-26.

Beyerlin, U., \& Marauhn, T. (2011). International environmental law. Portland: Hart.

Birnie, P., Boyle, A., \& Redgwell, C. (2002). International law and the environment (2nd ed.). Cambridge: Cambridge University Press.

Bodansky, D. (1993). The United Nations framework convention on climate change: Commentary. Yale Journal of International Law, 18(2), 451-558.

Brooks, D. (2015). Prioritizing "no significant harm" over "reasonable and equitable" in Governance of Aquifers. IISD Commentary.

Buchan, R. (2016). Cyberspace, non-state actors and the obligation to prevent transboundary harm. Journal of Conflict and Security Law, 21(3), 429-453.

Bussey, O. W. (2018). In good times and in bad: An international water law analysis of minute 323. Georgetown Environmental Law Review, 31(1), 157-182.

Convention on biological diversity (CBD) (1992) United Nations Treaty Series. Rio de Janeiro, 1760 (30619): 79 available from https://treaties.un.org/doc/Treaties/1992/06/19920605\%2008-44\%20PM/ Ch_XXVII_08p.pdf.

Convention on the Protection and Use of Transboundary Watercourses and International Lakes (Water Convention), Helsinki, 17 March 1992, United Nations Treaty Series, vol. 1936, No. 33207, p. 
269, available from https://treaties.un.org/doc/Treaties/1992/03/19920317\%2005-46\%20AM/Ch_ XXVII_05p.pdf

Craik, N. (2008). The international law of environmental impact assessment: Process, substance and integration. Cambridge: Cambridge University Press.

Cullet, P. (2007). Liability and redress for human-induced global warming: Towards an International Regime. Stanford Journal Of International Law, 43(1), 99-121.

de Vrese, P., Hagemann, S., \& Claussen, M. (2016). Asian irrigation, African rain: Remote impacts of irrigation. Geophysical Research Letters, 43, 3737-3745. https://doi.org/10.1002/2016GL068146

Dellapenna, J., \& Gupta, J. (Eds.). (2009). The evolution of the law and politics of water. Dordrecht: Springer Verlag.

Díaz, S., Pascual, U., Stenseke, M., Martín-López, B., Watson, R. T., Molnár, Z., et al. (2018). Assessing nature's contributions to people. Science, 359(6373), 270-272.

Drumbl, M. A. (2003). Trail smelter and the international law commission's work on state responsibility for internationally wrongful acts and state liability (pp. 03-06). Research Paper No: Washington \& Lee Public Law.

EkinsGupta, Boileau, P. P. (2019). Global Environment Outlook - GEO-6: Healthy Planet Healthy People. Cambridge: Cambridge University Press.

European Union (2002) Consolidated Versions of The Treaty on European Union and of The Treaty Establishing The European Community. Official Journal of the European Communities C 325/5; 24 December 2002 available from https://eur-lex.europa.eu/legal-content/EN/TXT/PDF/?uri=CELEX :12002E/TXT\&from=EN: Art. 174(2).

Faure, M. G., \& Nollkaemper, A. (2007). International liability as an instrument to prevent and compensate for climate change. Stanford Environmental Law Journal, 26, 123-180.

Faure, M. G., \& Peeters, M. (2011). Climate change liability. Cheltenham: Edward Elgar Publishing.

Filoso, S., Ometto Bezerra, M., Weiss, K., \& Palmer, M. A. (2017). Impacts of forest restoration on water yield: A systematic review. PLOS ONE, 12(8), e0183210. https://doi.org/10.1371/journ al.pone. 0183210

Foster, C. (2005). The ILC draft principles on the allocation of loss in the case of transboundary harm arising out of hazardous activities: Privatizing risk? Review of European Community \& International Environmental Law, 14, 265-282. https://doi.org/10.1111/j.1467-9388.2005.00447.x

Gaskell, G., Bauer, M., Durant, J., \& Allum, N. (1999). Worlds apart the reception of genetically modified foods in Europe and the US. Science, 285(5426), 384-387.

Government of Nepal and the Government of India (1996) Mahakali Treaty 1996 Treaty Between His Majesty's Government of Nepal and the Government of India Concerning the Integrated Development of the Mahakali River Including Sarada Barrage, Tanakpur Barrage and Pancheshwar Project. https://mowr.gov.in/sites/default/files/MAHAKALI_TREATY_19961.pdf. Assessed 28 March 2020

Government of the Republic of India and Government of the People's Republic of Bangladesh (1996) Treaty Between the government of the Republic of India and the government of the People's Republic of Bangladesh on Sharing of the Ganga/Ganges Waters at Farakka. https://gis.nacse.org/ tfdd/tfdddocs/568ENG.pdf. Assessed 28 March 2020: Article XII

Group of Experts (no date). Preliminary Draft of The Group of Experts-Draft Global Pact for the Environment, available from https://globalpactenvironment.org/uploads/EN.pdf

Gupta, J. (1997). The climate change convention and developing countries-from conflict to consensus? (p. 256). Dordrecht: Environment and Policy Series, Kluwer Academic Publishers.

Gupta, J. (2016). Towards Sharing Our Ecospace, S. Nicholson, S. Jinnah (eds.), New Earth Politics, MIT Press, 271-292.

Gupta, J. (2019). Editorial, what does UN environment's GEO-6 mean for INEA? INEA, 19(2), 145-150.

Gupta, J., \& Sanchez, N. (2013). The CBDR principle elaborated in relation to other principles of law. In M. C. Bassiouni, J. Gomula, P. Mengozzi, J. G. Merrills, R. N. Navia, A. Oriolo, et al. (Eds.), The global community yearbook of international law and jurisprudence, global trends: law, policy \& justice essays in honour of professor Giuliana Ziccardi Capaldo (pp. 23-39). New York: Oceana.

Gupta J., U. Ceylan (2020) The global environment outlook and its implications for international law: Is law increasingly falling behind, in Giulana Ziccardi Capaldo (ed.), The global community yearbook of international law and jurisprudence, Oxford University Press.

Gupta, J., \& Arts, K. (2018). Achieving the $1.5{ }^{\circ} \mathrm{C}$ objective: just implementation through a right to (sustainable) development approach. International Environmental Agreements: Politics, Law and Economics, 18, 11-18. 
HarremoësGeeMacGarvinStirlingKeysWynneGuedesVaz, P. M. A. J. B. S. (2001). Late lessons from early warnings: The precautionary principle 1896-2000. Luxembourg: Office for Official Publications of the European Communities.

International Court of Justice (ICJ) (1996) Reports of Judgments, Advisory Opinions and Orders: Legality of The Threat or Use of Nuclear Weapons-Advisory Opinion Of 8 July 1996. https://www.icjcij.org/files/case-related/95/095-19960708-ADV-01-00-EN.pdf Accessed 28 March 2020.

International Court of Justice (ICJ) (1997). Reports of Judgments, Advisory Opinions and Orders: Case Concerning the Gabcikovo-Nagymaros Project (Hungary/Slovakia) - Judgement of 25 September 1997. https://www.icj-cij.org/files/case-related/92/092-19970925-JUD-01-00-EN.pdf. Accessed 28 March 2020.

International Court of Justice (ICJ) (2010). Reports of Judgments, Advisory Opinions and Orders: Case Concerning Pulp Mills on The River Uruguay (Argentina V. Uruguay) - Judgment of 20 April 2010. https://www.icj-cij.org/files/case-related/135/135-20100420-JUD-01-00-EN.pdf. Accessed 28 March 2020.

International Law Commission (ILC) (1990). Yearbook of the International Law Commission: Report of the Commission to the General Assembly on the work of its fortieth session. 1988 Volume II Part Two. https://legal.un.org/ilc/publications/yearbooks/english/ilc_1988_v2_p2.pdf. Assessed 15 October.

International Law Commission (ILC) (2001a). Draft articles on Prevention of Transboundary Harm from Hazardous Activities, with commentaries. International Law Commission. https://legal.un.org/ilc/texts /instruments/english/commentaries/9_7_2001.pdf. Accessed on 27 March 2020.

International Law Association (ILA) (2001b). Draft articles on Responsibility of States for internationally wrongful acts adopted by the International Law Commission at its fifty-third session. International Law Association. https://www.refworld.org/docid/3ddb8f804.html. Accessed on 27 March 2020.

International Law Association (ILA) (2014). ILA Study Group on Due Diligence in International Law: First Report - Duncan French (Chair) and Tim Stephens (Rapporteur) 7 March 2014. International Law Association https://olympereseauinternational.files.wordpress.com/2015/07/due_diligence_-_first _report_2014.pdf. Accessed on 27 March 2019.

International Law Commission (ILC) (2006) Draft principles on the allocation of loss in the case of transboundary harm arising out of hazardous activities, with commentaries. https://legal.un.org/ilc/texts/ instruments/english/commentaries/9_10_2006.pdf. Accessed on 27 March 2020.

Knox, J. H. (2002). The myth and reality of transboundary environmental impact assessment. The American Journal of International Law, 96(2), 291-319.

Kulesza, J. (2016). Due Diligence in International Law. Brill: Nijhoff.

Kuokkanen, T. (2002). International Law and the Environment: Variations on a Theme, Brill.

Kyllönen, S. (2018). Climate Change, No-Harm Principle, and Moral Responsibility of Individual Emitters. Journal of Applied Philosophy, 35(4), 737-758.

Larson, R. (2016). Governing water augmentation under the Watercourse Convention. Water International, $41(6), 866-882$.

Maull, H. (eds.) (2018). The rise and decline of the post-cold war international order. Oxford University Press.

Mayer, B. (2014). State responsibility and climate change governance: A light through the storm. Chinese Journal of International Law, 13(3), 539-575.

McIntyre, O. (2017). Substantive rules of international water law. In A. Rieu-Clarke, A. Allan, \& S. Hendry (Eds.), Routledge Handbook of Water Law and Policy (pp. 234-259). New York: Routledge.

Newman, E., Thakur, R., \& Tirman, J. (Eds.). (2006). Multilateralism under challenge? Power, international order, and structural change. Tokyo: United Nations University Press.

PCA Indus Waters Kishenganga Arbitration (Pakistan v. India) Partial Award, 18 February 2013, 48, paragraph 59.

Peel, J., \& Osofsky, H. M. (2015). Climate Change Litigation: Regulatory Pathways to Cleaner Energy. Cambridge: Cambridge University Press.

Permanent Court of Arbitration (PCA) (2013) In the Matter of the Indus Waters Kishenganga Arbitrationbefore-the Court of Arbitration Constituted in Accordance with the Indus Waters Treaty 1960 Between the Government of India and the Government of Pakistan Signed on 19 September 1960 -Between- the Islamic Republic Of Pakistan-and-the Republic of India. https://pcacases.com/web/sendAttach/1681. Accessed 28 March 2020.

Pratap, R. (2018). Building peace over water in South Asia: The watercourses convention and SAARC. Athens Journal of Law, 4(1), 7-26.

Qadir, M., Jiménez, G. C., Farnum, R. L., Dodson, L. L., \& Smakhtin, V. F. (2018). Water collection: Challenges beyond technology. Water, 10, 372. https://doi.org/10.3390/w10040372 
Qureshi, W. A. (2017). Indus Basin Water Management under International Law, 25 U. Miami Int'1 \& Comp. L. Rev. 63.

Qureshi, W. A. (2018). Dispute resolution mechanisms: An analysis of the indus waters treaty. Pepperdine Dispute Resolution Law Journal, 18(1), 75-116.

Rao, P. S. (2002). Prevention of transboundary harm from hazardous activities: A subtopic of international liability. Environmental policy and Law, 32(1), 22-27.

Rockström, J., Steffen, W., Noone, K., Persson, A., Chapin, F., Lambin, F., et al. (2009). Planetary boundaries: Exploring the safe operating space for humanity. Ecology and Society, 14(2), 32.

Salman, S. (2010). Downstream riparians can also harm upstream riparians: The concept of foreclosure of future uses. Water International, 33(4), 350-364.

Salman, S., \& Uprety, K. (1999). Hydro-politics in South Asia: A comparative analysis of the Mahakali and the Ganges Treaties. Natural Resources Journal, 39(2), 295-343.

Sands, P., \& Peel, J. (2012). Principles of international environmental law. Cambridge: Cambridge University Press.

Sands, P. (2003). Principles of International Environmental Law. Cambridge: Cambridge University Press, 2nd Ed.

Shrestha, R. K., Ahlers, R., Bakker, M., \& Gupta, J. (2010). Institutional dysfunction and challenges in flood control: A case study of the Kosi flood 2008. Economic and Political Weekly, 45(2), 45-53.

Simms, V. (2010). Making the rain: Cloud seeding, the imminent freshwater crisis, and international law. The International Lawyer, 44(2), 915-938.

Single European Act, Luxembourg and The Hague, 17 February 1986 and 28 February 1986, United Nations Treaties Series, vol 1754, available from https://treaties.un.org/doc/Publication/UNTS/Volum e\%201754/volume-1754-I-30614-English.pdf: Art. 130 R (2).

Steffen, W., Richardson, K., Rockström, J., Cornell, S., Fetzer, I., Bennett, E., et al. (2015). Planetary boundaries: Guiding human development on a changing planet. Science, 347(6223), 736-747.

Takano, A. (2018). Due diligence obligations and transboundary environmental harm: Cybersecurity applications. Laws, 7(4), 36-47.

Termyn, C. (2018). Federal Indian reserved water rights and the no harm rule. Columbia Journal of Environmental Law, 43(2), 533-574.

Trail Smelter Case (United States of America, Canada), April 16, 1938, and March 11, 1941. United Nations Reports of International Arbitral Awards. https://legal.un.org/riaa/cases/vol_III/1905-1982. pdf. Accessed 17 November 2019.

Treaty on European Union (Maastricht Treaty), Maastricht, 07 February 1992, United Nations Treaties Series, vol 1755, 1756, 1757, 1758, 1759, available from https://treaties.un.org/doc/Publication/UNTS/ Volume\%201757/volume-1757-I-30615-English.pdf.

Trouwborst, A. (2007). The precautionary principle in general international law: Combating the Babylonian confusion. Review of European Community \& International Environmental Law, 16(2), 185-195.

UNGA Resolution 41/128, Declaration on the Right to Development, A/RES/41/128 (4 December 1986), available from https://documents-dds-ny.un.org/doc/RESOLUTION/GEN/NR0/496/36/IMG/NR049 636.pdf?OpenElement.

UNGA Resolution 70/1, Transforming our world: the 2030 Agenda for Sustainable Development (Agenda 2030), A/RES/70/1 (25 September 2015), available from https://undocs.org/en/A/RES/70/1.

UNGA, First report on the protection of the atmosphere Prepared by Mr. Shinya Murase, Special Rapporteur, A/CN.4/667, para.5 (14 February 2014), available from https://digitallibrary.un.org/record/77013 $2 ? \ln =$ en.

UNGA (1972) Resolution 2994/XXVII, 2995/UVII and 2996/XXII, Declaration of the United Nations Conference on the Human Environment (Stockholm Declaration), A/RES/2994(XXVII), A/ RES/2995(XXVII), and A/RES/2996(XXII) (15 December 1972) available from https://wedocs.unep. org/bitstream/handle/20.500.11822/29567/ELGP1StockD.pdf?sequence=1\&isAllowed=y.

UNGA (1992) Report of the United Nations Conference on Environment and Development, Annex I Rio Declaration on Environment and Development (Rio Declaration), A/CONF.151/26 (Vol. I) (3-14 June 1992) available from https://www.un.org/en/development/desa/population/migration/generalassembly/ docs/globalcompact/A_CONF.151_26_Vol.I_Declaration.pdf.

UNGA (1997) General Assembly Resolution 51/229, Convention on the Law of the Non-navigational Uses of International Watercourses, A/RES/51/229 (21 May 1997), available from https://treaties.un.org/ doc/source/docs/A_RES_51_229-Eng.pdf.

United Nations Framework Convention on Climate Change (UNFCCC), New York, 9 May 1992, Treaty Series, vol. 1771, No. 30822, p. 107, available from https://treaties.un.org/doc/Treaties/1994/03/19940 321\%2004-56\%20AM/Ch_XXVII_07p.pdf. 
Uprety, K., Salman, S., (2011). Legal aspects of sharing and management of transboundary waters in South Asia: Preventing conflicts and promoting cooperation. Hydrological Sciences Journal, 56(4), 641-661.UN General Assembly Resolution 47/188, United Nations Convention to Combat Desertification in those Countries Experiencing Serious Drought and/or Desertification Particularly in Africa (UNCCD), A/RES/47/188 (14 October 1994), available from https://treaties.un.org/doc/source/ docs/A_RES_47_188-Eng.pdf.

Voigt, C. (2008). State responsibility for climate change damages. Nordic Journal of International Law, 77, $1-22$.

Weiss, C. (2006). Can there be science-based precaution? Environmental Research Letters, 1(1), 1-7.

World Trade Organization (1998) EC Measures Concerning Meat and Meat Products (Hormones). (WT/ DS26/AB/R - WT/DS48/AB/R, 16 January 1998). Available from https://www.wto.org/english/trato p_e/dispu_e/hormab.pdf.

Publisher's Note Springer Nature remains neutral with regard to jurisdictional claims in published maps and institutional affiliations. 